\title{
THE COLLECTIVE UNCONSCIOUS IN THE NOVELS OF PAULO COELHO
}

\author{
Prof. Dr. Jagdish Joshi \\ Dr. Neha Arun Hariyani
}

\begin{abstract}
The Brazilian author Paulo Coelho is a winner of Guinness Book of World Records and the world ambassador of psychological literature. The present paper intends to study the selected works of Paulo Coelho in the light of the reputed American mythologist and psychoanalyst Joseph Campbell's theory on Emanations which is depicted in his seminal work The Hero With A Thousand Faces. Campbell's thoughts revolving around mythology, metaphysics, and psychology, forming the structural principles of literature, do essentially evolve a story pattern. Campbell like Freud and Jung regards dreams highly significant, as dreams provide a thoughtstructure and express the unconscious. Campbell's psychoanalytical theory largely bears on that of Jung. For Campbell myths and dreams have their origin in the unconscious wells of fantasy, though they may differ on some aspects. He considers the mythic heroes as archetypes representing the collective unconscious and, also as the versions of those archetypes both in spiritual and psychological terms. The paper intends to develop the mythical and psychological bearings in the novels of Coelho as it describes the adventure, quest, and transformation of the hero, supernatural power, occult rituals, destiny, and the interpretations of dreams in the Jungian terms, besides retaining their fictional element. Coelho's novels The Pilgrimage, The Alchemist and The Zahir very well exemplify that how can a literary writer translate the myths which contain the eternal values afresh in terms of the existing realities through the use of the modern psychology.
\end{abstract}

Key Words: Emanation, Mythology, Psychology, Myths, Dreams, Collective unconscious, Mythic Heroes, Archetypes, Psychoanalysis

The Brazilian author Paulo Coelho is a winner of Guinness Book of World Records and the world ambassador of psychological literature. The works of this bestseller contemporary writer are widely read all over the globe and are translated in more than seventy-one languages of the world. The present paper intends to study the selected works of Paulo Coelho in the light of the reputed American mythologist and psychoanalyst Joseph Campbell's theory on Emanations which is depicted in his seminal work The Hero With A Thousand Faces. Campbell agrees with the psychoanalysts like Sigmund Freud, Carl G. Jung, Wilhelm Stekel, Otto Rank, Karl Abraham, Geza Roheim who have developed modern lore of dream and myth interpretation 
and who believe that myths are of the nature of dreams and dreams are symptomatic of the dynamics of the psyche. Campbell's thoughts revolving around mythology, metaphysics, and psychology, forming the structural principles of literature, do essentially evolve a story pattern. Campbell like Freud and Jung regards dreams highly significant, as dreams provide a thoughtstructure and express the unconscious. Campbell considers the mythic heroes as archetypes representing the collective unconscious and, also as the versions of those archetypes both in spiritual and psychological terms. The Collective Unconscious refers to structures of the unconscious mind which are shared among beings of the same species. The human collective unconscious is populated by instincts and archetypes are universal symbols such as the Great Mother, the Wise Old Man, the Shadow, the Tower, Water, the Tree of Life and so on. John P. Dourley sums up Jung's interpretations of the divine and the psyche: "Thus what is both exciting and liberating to some and disturbing to others in Jung's understanding of the natural experience of the divine is that it is wholly intrapsychic, a function of the unconscious in its impact on consciousness understood as two dimensions of a single all-inclusive organism, the human psyche. The psyche, thus expanded, includes the personal ego and its consciousness within the embrace of something much wider" (Dourley 179). Dream has a great significance in Jungian psychoanalysis. Edward C. Whitmont rhetorically illustrates the importance of Jungian dream: "Why do we usually dream images rather than logical thoughts? Why does the psyche bother us with seemingly irrational or at least difficult-to-comprehend symbolic fantasies if it wants to help us overcome our impasses? Might the purpose not be accomplished more easily if dreams and fantasies were expressed in plainly understandable, logical, everyday language?" (Whitmont 28)

For Jung, the unconscious is always positive. It is the source of meaning and determines value. As Susan Rowland comments: Jungian ideas differ significantly from Freudian psychoanalysis in seeking to honour the unconscious rather than fearing it. The Jungian unconscious is conceptually far superior to the ego: it is the source of meaning, feeling and the possibility of finding value in human life. There is a lesser aspect to the unconscious formed (like Freud's) upon the lines of Oedipal repression via the person's own family relationships. Jung calls this the 'personal unconscious' and it does not detract from the enormous positive potential of the unconscious proper. (Rowland 29)

Like many mythologists and psychoanalysts Campbell also believes that myths contain eternal values. The literary writers can translate those values afresh in terms of the existing realities through the use of the modern psychology. The paper intends to develop the mythical and psychological bearings in the novels of Coelho as it describes the adventure, quest, and transformation of the hero, supernatural power, occult rituals, destiny, and the interpretations of dreams in the Jungian terms, besides retaining their fictional element. Interestingly, Coelho is influenced by the psychoanalytic theory of Jung as Rajendra Kumar Dash, while making a comparative study of Hermann Hesse's Siddhartha and Paulo Coelho's The Alchemist observes: "When Hesse was personally influenced by Jung through psychoanalysis, Coelho accessed Jung through the latter's psychology via books" (Dash 18).

Campbell's psychoanalytical theory largely bears on that of Jung. For Campbell myths and dreams have their origin in the unconscious wells of fantasy, though they may differ on some aspects. To quote Campbell: But if we are to grasp the full value of the materials, we must note that myths are not exactly comparable to dream. Their figures originate from the same sources - the unconscious wells of fantasy - and their grammar is the same, but they are not the 
spontaneous products of sleep. On the contrary, their patterns are consciously controlled. And their understood function is to serve as a powerful picture language for the communication of traditional wisdom. (Campbell 220).

In view of Campbell's observation, the old woman's dog, in The Pilgrimage presumably the manifestation of the image of the devil, characterized by the gypsy, unquestionably acquires a central position, for the dog enables Paulo to move backward and forward on a psychic plane, at the same time leaving him hypnotized as he gazes into the eyes of the dog, presenting fear, fantasy and nervousness, shared beliefs of the human race (the collective unconscious). The image of the dog becomes the archetype because the dog no more appears exactly as it exists. It appears as an agent of evil, the devil, the gypsy and transforms itself into man while Paulo himself becomes the dog. So, the fear of the dog arouses fantasy. The archetypal image of the dog becomes more clairvoyant the moment it drives away the fear and nervousness from Paulo and enables him to resume his journey through more mystic zones through agape (love). Similarly, the lamb that substitutes Petrus to become Paulo's guide eventually emerges as an archetypal image of a redeemer, though traditionally the lamb is an archetypal image of innocence. Hence, the use of Campbellian psychoanalysis enables the character of the lamb to emerge as a divine being that helps Paulo to bring about his self-realization. Paulo's vision of the saints makes Paulo realize that he has lost a considerable amount of agape and purity and enables him to regain that sanctity because the love that consumes has returned as the saints smile. The saints emerge as archetypes. They help Paulo come back to the primordial state of childhood innocence. As dream holds a pivotal position in The Alchemist, it is also regarded as the essential component for adventure in The Pilgrimage. Petrus explains: "We must never stop dreaming. Dreams provide nourishment for the soul, just as meal does for the body" (Coelho 61, 1987). Obviously, dream in The Pilgrimage is impregnated with a wider meaning that also includes relentless quest for destiny.

The analysis of The Alchemist in the light of Campbell's theory of dream, fantasy, and the unconscious, may also allow one to look at the recurrent motif of dream in terms of Jung's psychoanalytic theory. Santiago's vision of a little girl twice in his unfinished dream telling Santiago about the hidden treasure, becomes the archetype because the desire she arouses in Santiago for the treasure remains unmitigated like the dream that remains unfinished. The old woman in The Alchemist interprets the meaning and nature of dreams in Campbellian term as she remarks: "And dreams are the language of God. When he speaks in our language, I can interpret what he has said. But if he speaks in the language of the soul, it is only you who can understand" (Coelho 12, 1988). The entire narrative in The Alchemist, starting from Santiago's unfinished dream, the little girl, the pyramids, the dream interpreters, Urim and Thummim, the daughter of the merchant, Fatima, the Englishman, the Alchemist (more than two hundred years old) the desert, the wind, the oasis, the chief of the Arab soldiers and the treasure itself are nothing but the extensions of the same dream, interacting and unravelling themselves like the collective unconscious, arousing in Santiago fear, fantasy and desire. Santiago's encounter with the Alchemist, a powerful man able to transform lead into gold, analysed in the light of Campbellian thought emerges as an archetype. It is also interesting to mark that the treasure that Santiago is hoping to find in the Pyramids of Egypt but never finds there. It is the alchemist that makes Santiago's dream for the treasure (gold) realized by turning the lead into gold and practically giving a part of that gold, eventually to be robbed off. At a deeper level, Santiago's journey through the desert, the sand, the wind the Sun and the hand that writes all, are nothing 
but the external manifestations of the meditation into his own interior. The blowing of the wind faster and faster, known as simum, in harmony with all other forces deriving strength and enlightenment eventually turn Santiago into the wind, transforming him into a perfect disciple of the alchemist who understands the glory of God. This learning of Santiago is to be tested before Santiago's dream is to realize in the Pyramids of Egypt, described as serene and majestic in the novel, as the alchemist makes it clear to Santiago:

What you still need to know is this: before a dream is realized, the Soul of the World tests everything that was learned along the way. It does this not because it is evil, but so that we can, in addition to realizing our dreams, master the lessons we've learned as we've moved toward that dream. That's the point at which most people give up. It's the point at which, as we say in the language of the desert, one dies of thirst just when the palm trees have appeared on the horizon.

(Coelho126-27, 1988)

So, Santiago's success to make himself invisible by raising wind, analysed in the light of the psychoanalytical thought is the externalization of his repressed desires, fear, and fantasy to express the shared beliefs in a psychoanalytical way.

However, The Zahir presents a very eloquent example of the collective unconscious in Mikhail's vision of the small girl on a tree as he passes by the tree, and even after the tree is cut. The recurrence of the female child's image as it enters in Mikhail's body often referred to as the voice in the narrative is a divine energy, and also the epileptic effect that renders Mikhail unconscious, driving Mikhail back to the primitive stage. The image of the little girl that is visible to and communicates with Mikhail only, is almost the woman that Mikhail fantasizes a dream like object, not an earthly girl but a supernatural being surrounded with a halo and floating in the air. The girl, the immaculate conception or 'the voice' plays a vital role throughout the narrative. It is the voice that encourages Mikhail to go to the book-signing ceremony. And it is again the voice that tells Mikhail that before he is twenty-two, a woman from far away will come and carry him off to see the world, to fullfil a mission "to spread the true energy of love throughout the world" (Coelho 198, 2005). It is the voice alone that enables Mikhail's dead father communicate with his mother through Mikhail. So, the voice is both the source and the medium as well to establish a communion between the mystic world and the world of human psyche. And the epileptic fits are the symptoms of Mikhail's connection with the Power. And it is the 'voice' alone that tells Mikhail as when and how to see Esther, besides making other predictions that always come true. In the course of the journey the hero is made to pass through the realization as he allows his consciousness to coincide with the memories of his ex-wives and also with those of Marie (the hero's girlfriend whose love for the hero deepens when Marie thinks of her own boyfriend, her neighbour) wherein the hero attempts to locate the space for Esther only to find that she has become the Zahir ( a myth) in the Jungian psychoanalytic context only to exist in the deep mazes of the hero's psyche (consciousness), representing the collective unconscious of man's destiny in Jungian terms. Thus, the journey of the hero in The Zahir from Campbellian perspective becomes not only the hero's individual journey but also that of the entire human race in quest of love. 


\title{
Works Cited
}

- Campbell, Joseph. The Hero with a Thousand Faces. California: New World Lib., 1949 rpt. 2008. Print.

- Coelho, Paulo. The Pilgrimage. London: Thorsons, 1987 rpt. 2015. Print.

- ... The Alchemist. Nodia: Harper Collins, 1988 rpt. 2016. Print.

- $\quad$... The Zahir. London: Thorsons, 2005 rpt. 2014. Print.

- Dourley, John P. "The Religious Implications of Jung's Psychology". Journal of Analytical Psychology. 40.2 (1995): 177-203. https://www.deepdyve.com. Web. 16 Nov. 2020.

- Whitmont, Edward C. The Symbolic Quest: Basic Concepts of Analytical Psychology. New Jersey: Princeton UP, 1969 rpt. 1978. 28. Print.

- Roland, Susan. Jung: A Feminist Revision. Cambridge: Polity Press, 2002. 29. Print.

- Dash, Rajendra Kumar. "Alchemy of the Soul: A Comparative Study of Hermann Hesse's Siddhartha and Paulo Coelho's The Alchemist”. Search. 2 (July 2012): 17-23. ddceutkal.ac.in. Web. 8 Nov. 2020.

\author{
Dr. Jagdish Joshi \\ Professor - Director \\ UGC-Human Resource Development Centre \\ Gujarat University, Ahmedabad \\ \& \\ Dr.Neha Arun Hariyani \\ Associate Professor (English) \\ S.B.Garda Arts \& P.K.Patel College of Commerce, Navsari. \\ Email: danineha@hotmail.com
}

